\title{
GDZIE MIESZKA JĘZYK?
}

\author{
WŁADYSŁAW ZABROCKI
}

\begin{abstract}
The article is devoted to the problems of the ontological assumptions of linguistics. It is argued that the thesis on the diversity of these assumptions goes beyond the classic positions in the dispute over language universals. The dependence of ontological assumptions on the empirically established linguistic theories is indicated.
\end{abstract}

Key words: ontological assumptions, linguistic theories, language universals, Tadeusz Zgółka

Dedykuje poniższy tekst mojemu nauczycielowi, profesorowi Tadeuszowi Zgółce w 75. rocznicę urodzin.

Tadeusz Zgółka na spotkaniu z autorami książki Język w refleksji teoretycznej. Zarys dziejów (Bogusławski i Drzazgowska, 2016) zapytał: Gdzie mieszka język? $\mathrm{W}$ zamierzeniu autora pytania jest oczywiste, że język gdzieś mieszka. Zgodnie z klasycznymi stanowiskami uczestników dyskusji o uniwersaliach język mógłby mieszkać w platońskiej jaskini, w arystotelesowskich substancjach pierwszych, w powiewach głosu, w umysłowych konceptach czy kartezjańskiej szyszynce. Nie łatwo wyliczyć wszystkie możliwe miejsca.

W nieco innej perspektywie język może mieszkać w przestrzeniach ponadjednostkowych lub indywidualnych. Tych pierwszych może być bardzo dużo, tak jak wiele jest wspólnot komunikatywnych (L. Zabrocki, 1963).

Te drugie też są zróżnicowane. Mogą to być anatomiczne fragmenty umysłu/mózgu (jak zakłada się w teorii generatywistycznej Chomsky,ego), bądź całe ciała (jak przyjęto w ucieleśnionej semantyce).

Postaram się przedstawić argumenty przeciwne tezie o niechronologicznym krążeniu idei $\mathrm{w}$ zakresie zajmowanych stanowisk $\mathrm{w}$ sporze o charakter miejsca zamieszkania języka (Katz, 1981). 
Zacznę od zarysowania płaszczyzny teoretyczno-filozoficznej, która będzie stanowić punkt odniesienia i swoiste tertium comparationis dla porównania wspomnianych, często mocno heterogenicznych stanowisk w kwestii sposobu istnienia języka. Zaproponowałem kiedyś podział możliwych badań kognitywnych nad językiem na dotyczące kompetencji indywidualnej, kompetencji społecznej i kompetencji uniwersalnej (stanowisko przyjęte np. przez Kleszczowa 2012: 215) Podział ten od początku nie był traktowany jako rozłączny. Wyróżniłem jako przedmiot badań lingwistyki generatywnej kompetencję uniwersalną i jednocześnie społeczną (por. uwagi Ritter 1994: 40).

Dzisiaj nie podzielałbym mocnych założeń ontologicznych, które wspierały przedstawiony wyżej podział. Wolałbym mówić o intuicjach indywidualnych (badanych $\mathrm{w}$ psycholingwistyce), intuicjach społecznych (badanych często $\mathrm{w}$ ramach lingwistyki antropologicznej czy socjolingwistyki) i intuicjach uniwersalnych (badanych w ramach rozmaitych odmian językoznawstwa ogólnego, czy teoretycznego).

Myślę, że pojęcie kompetencji (z którego sam twórca, Noam Chomsky, wydaje się ostatnio rezygnować na rzecz mocniejszego ontologicznie pojęcia organu językowego) przynosi za wiele niejasności natury ontologicznej - np. nieuchronne jest pytanie o podmiot tej wiedzy językowej.

Uznanie intuicji za dziedzinę empirycznego osadzenia teorii językoznawczej nie pociąga za sobą takiego pytania. Intuicje rodzą się w przestrzeni wyznaczonej przez wspólnotę praktyków, której rodzajem jest np. wspólnota komunikatywna (por. L. Zabrocki, 1963) lub w sferze tzw. systemu nieświadomych przesłanek naszego działania (por. Kahneman, 2012). Nie ma tutaj naglącej potrzeby pytania o niezależną od teorii wiedzę językową, gdyż intuicje są po prostu elementem procesu poznawczego lingwisty i nie da się ich oddzielić od teorii (por. Popper i jego teza o impregnowaniu doświadczenia przez teorię).

W ramach językowej wspólnoty praktyków możemy wyróżnić trzy zdolności składające się na poczucie językowe (Sprachgefühl) Jedna będzie związana z akceptowalnością indywidualną, druga $\mathrm{z}$ poczuciem normatywnym charakterystycznym dla wymiaru społecznego wspólnoty, a trzecia $z$ uniwersalnym, gatunkowym poczuciem wspólnoty.

Oczywiście, nie uchwycimy poczucia językowego (intuicji językowej), bez teorii językoznawczej. Wyodrębnienie, klasyfikacja aktów intuicji (oceny) na uniwersalne lub społeczne jest niemożliwa bez uprzedniej perspektywy teoretycznej. Wyróżnimy dwojaki sens uniwersalnego charakteru językowych intuicji. Jeden, który związany jest $\mathrm{z}$ oczywistym założeniem o zdolności do opanowania dowolnego języka przez każdego przedstawiciela gatunku homo sapiens. Drugi jest regulowany przez teorię uniwersaliów językowych. Dane empiryczne oparte na intuicjach dotyczących granic przesunięć elementów przez reguły transformacyjne mogą funkcjonować tylko w ramach odpowiedniej perspektywy językoznawczej. Przy czym nie- 
koniecznie wiązałbym taki punkt widzenia $\mathrm{z}$ instrumentalizmem całościowym Quine’a. Raczej skłaniałbym się do realizmu w sensie Poppera.

Czyli istnienie języka ma trzy zasadnicze wymiary (por. Zabrocki, 2006):

indywidualny - badany np. w powstałym w XIX wieku paradygmacie historyczno-porównawczym.

społeczny - badany np. w ramach szkoły praskiej.

uniwersalny - badany np. w szkole Chomsky'ego.

Założeniem omawianych powyżej stanowisk było rozumienie języka jako jednorodnego bytu możliwego do całościowego uchwycenia przy pomocy również jednorodnych środków poznawczych. Stąd sensowne było pytanie o ontologiczny status języka.

Wypada w tym miejscu zauważyć, że wiele obecnie dynamicznie rozwijających się kierunków refleksji nad językiem wydaje się dystansować od tego mocno zdroworozsądkowo ugruntowanego założenia. Akcentuje się heterogeniczny charakter fenomenów językowych. Powoli bezprzedmiotowe staje się pytanie o lokalizację języka. W szeroko pojętej lingwistyce funkcjonalnej badane są pogranicza języka i innych dziedzin praktyki kulturowej, gdzie zachowanie ,językowe” spełnia różnorodne funkcje adaptacyjne. Używając terminologii społeczno-regulacyjnej teorii kultury Jerzego Kmity można powiedzieć, że językowa wspólnota praktyków spełnia się $\mathrm{w}$ realizowaniu funkcji komunikacyjnej, akwizycyjnej, instytucjonalnopedagogicznej, poznawczej (w tym naukotwórczej), magicznej, religijnej, światopoglądotwórczej itp.

W lingwistyce postmodernistycznej język mieszka wszędzie, bądź nigdzie (co na to samo wychodzi).

Ważnym procesem w zakresie zmian perspektywy lingwistycznego postrzegania rzeczywistości semiotycznej jest kierowanie reflektorów poznawczych w ramach dwóch osi: wertykalnej i horyzontalnej.

Najbardziej spektakularna jest tendencja do horyzontalnego rozszerzenia przedmiotu badań językoznawstwa. Klasycznym przykładem jest przyjmowanie kolejno perspektywy fonolologicznej, składniowej, semantycznej i pragmatycznej. Na poziomie fonologicznym (szkoła praska) można było mówić o niezbędnym zróżnicowaniu dźwiękowym dla wyrażaniu znaczeń. Składnia generatywna przynosi rozszerzenie perspektywy o aspekt rekurencji. Kolejna propozycja to poszerzenie horyzontu o elementy różnicujące znaczenie: deiktyczne, funkcjonalne w sensie teorii aktów mowy i związane z implikaturą. Kolejny krok to poszerzenie już w ramach paradygmatu postmodernistycznego o systemy komunikowania zwierząt, roślin i dalej o elementy całej niszy ekologicznej (Puppel, 2002) Poszerzenie obejmuje także gesty i inne elementy uwzględniane w spojrzeniu multimodalnym. Można to zróżnicowanie opisać rozszerzeniem materiału empirycznego bądź przedmiotu 
badan. Granice stanowią tutaj totalny holizm vs absolutny minimalizm. Czy totalny holizm to wpływy całego kosmosu na język lub odwrotnie? Można zawsze dalej: Język jest tym urządzeniem, które pozwala istotom mówiacym, a wśród nich i nam, ludziom, mieszkańcom planety Ziemia, autentycznie wspótdziałać z Bogiem, dawca zdolności językowej, w rzadach nad tym wszechświatem, do którego należymy (Bogusławski, Drzazgowska 2016: 788).

Bliski absolutnego minimalizmu jest następujący akord w grze generatywistycznej, gdzie wyraźnie widoczny jest też dystans wobec ewolucjonistycznej perspektywy badawczej. Warto przytoczyć dłuższy fragment:

FLB as a whole thus has an ancient evolutionary history, long predating the emergence of language, and a comparative analysis is necessary to understand this complex system. By contrast, according to recent linguistic theory, the computations underlying FLN may be quite limited. In fact, we propose in this hypothesis that FLN comprises only the core computational mechanisms of recursion as they appear in narrow syntax and the mappings to the interfaces. If FLN is indeed this restricted, this hypothesis has the interesting effect of nullifying the argument from design, and thus rendering the status of FLN as an adaptation open to question. Proponents of the idea that FLN is an adaptation would thus need to supply additional data or arguments to support this viewpoint. (Hauser, et al. 2002: 1572).

Inne zróżnicowanie to pionowe, wertykalne, które będę też interpretował jako wyznaczone przez opozycję esencjalizm vs fenomenalizm.

Głębokie, sięgające istoty języka badania mogą obejmować również szeroką perspektywę. Tak jest w przypadku głębokiej ekolingwistyki (Krawczak, 2017).

Najbardziej zaangażowane po stronie esencjalizmu wydają się być teorie generatywistyczne, gdzie można mówić o uniwersalnych intuicjach, które są klarowane przez teorię odnoszącą się do wyidealizowanej gramatyki uniwersalnej. Warto zaznaczyć, że obecnie (w ramach programu minimalistycznego) idealizacyjne zaangażowanie generatywistów znacznie słabnie.

Na drugim biegunie znajdują się badania korpusowe, gdzie przedmiotem uwagi może być dowolne jednostki językowe, przy czym przyjmuje się zasadę, że im więcej, tym lepiej.

W tym miejscu chciałbym postawić dwa pytania:

Czy są granice i jaki wpływ w tym względzie ma ontologia?

Rozważmy problem na przykładzie językoznawstwa historyczno-porównawczego i ewolucyjnego. To drugie w sposób oczywisty pociąga udział w wyjaśnianiu przesłanki, którą stanowi prawo doboru naturalnego (por. Żywiczyński i Wacewicz, 2015). Jest to złamanie eksplanacyjnej autonomii językoznawstwa. Angażowana jest aparatura często wysoko zmatematyzowanej wersji współczesnego ewolucjonizmu, który stanowi fundament biologii od czasów Darwina. Podejmowane na terenie językoznawstwa XIX wiecznego (min. przez Schleichera) próby adaptacji ewolucjonizmu wykraczały poza językoznawstwo historyczno-porównawcze (Koerner, 
1982). Wydaje się, iż tam gdzie językoznawcy historyczno-porównawczy sięgają po procedurę wyjaśniania i angażują przesłanki wzięte spoza językoznawstwa (na przykład słynne prawo najmniejszego wysiłku czy prawo wyobrażeń niedostatecznie różnych), w gruncie rzeczy mamy do czynienia z budową przesłanek, które nie pochodzą z innej dziedziny aktywności naukowej (np. psychologii czy biologii), ale są wynikiem własnej aktywności teoriotwórczej językoznawców - mogą świadczyć o ontologicznym zaangażowaniu, ale nie są związane z procedurami funkcjonującymi poza językoznawstwem. Osobna kwestia to zdroworozsądkowa proweniencja tych przesłanek (por. Zgółka, 1980).

Powstaje pytanie, czy postulat autonomii językoznawstwa jest pochodną zaangażowania ontologicznego teorii językoznawczych. Stanowi on niewątpliwie wspólną płaszczyznę językoznawstwa historyczno-porównawczego, strukturalistycznego i generatywnego. Wiąże się z poszukiwaniem przesłanek wyjaśniających $\mathrm{w}$ granicach myśli językoznawczej lub proponowanej często ad hoc teorii tylko z nazwy zewnętrznej wobec autonomicznej refleksji językoznawczej - wspomniane wyżej prawa wyjaśniające zmiany językowe, behawiorystyczne redukcje strukturalistów amerykańskich czy natywistyczno-biologiczne próby Chomsky’ego).

Inaczej wygląda sytuacja, gdy angażowany jest aparat poznawczy wypracowany w ramach innej od językoznawstwa nauki do opisu i wyjaśniania zjawisk językowych. Właśnie to ma miejsce w przypadku językoznawstwa ewolucyjnego, a także np. neurolingwistyki. Historia badań nad językiem dostarcza wiele przykładów takiej postawy badawczej. Można badać język z pozycji socjologii, fizyki, matematyki, logiki, literaturoznawstwa czy wreszcie nauk stosowanych, gdzie liczy się praktyczny efekt (jak w przypadku automatycznego tłumaczenia), a nie wierność założeniom wziętym z myśli językoznawczej. Stąd krytyka badań z zakresu np. psychologii języka czy ewolucji języka z pozycji wybranego paradygmatu autonomicznego językoznawstwa jest w sposób oczywisty skazana na porażkę.

Warto na koniec zaznaczyć, że tytułowe pytanie prof. Zgółki nie powinno skłaniać do nadmiernie uproszczonych poszukiwań, czego wyrazem byłoby dosłowne przeniesienie na grunt ontologicznych założeń językoznawstwa znanych ze sporu o uniwersalia stanowisk - np. platonizm Katza (Katz, 1981) versus konceptualizm Chomsky’ego (Chomsky, 1965). Ontologiczne oblicza języka są tak różnorodne, że nie należy się spodziewać wyczerpania możliwych spojrzeń, tworzonych przez pryzmat coraz to nowszych perspektyw badawczych.

\section{Bibliografia}

Bogusławski, A. i E. Drzazgowska. 2016. Język w refleksji teoretycznej: przekroje historyczne. Warszawa: Uniwersytet Warszawski, Katedra Lingwistyki Formalnej.

Chomsky, N. 1965. Aspects of the theory of syntax. Cambridge, Mass.: M.I.T. Press. 
Hauser, M.D., Chomsky, N. i W.T. Fitch. 2002. "The faculty of language: what is it, who has it, and how did it evolve?". Science 298. 5598, 1569-1579.

Kahneman, D. 2012. Thinking, fast and slow. London: Penguin.

Katz, J.J. 1981. Language and other abstract objects. Totowa, N.J.: Rowman and Littlefield.

Kleszczowa, K. 2012. Tajemnice dynamiki języka: księga jubileuszowa. Katowice: Wydawnictwo Uniwersytetu Śląskiego.

Koerner, K. 1982. „The Schleicherian paradigm in linguistics”. General linguistics 22.1. 1-39.

Krawczak, M. 2017. „Poznańska szkoła ekolingwistyki”. Scripta Neophilologica Posnaniensia XVII. 145-192.

Rittel, T. 1994. Metodologia lingwistyki edukacyjnej: Rozwój języka. Kraków: Wydawnictwo Naukowe WSP.

Puppel, S. 2002. "A nonmonotonic account of human verbal communicative behaviour versus animal communication: an attempt at converging the linguistic and information processing perspectives". Lingua Posnaniensis 44. 131-144.

Zabrocki, W. 2006. Psychologizm i socjologizm $w$ dziejach transformacyjno-generatywnej refleksji nad językiem naturalnym. Stuttgart: Ernst Klett Sprachen.

Zabrocki, W. 2018. „Głos w dyskusji nad książką Andrzeja Bogusławskiego i Ewy Drzazgowskiej: Język w refleksji teoretycznej. Przekroje historyczne”. Investigationes linguisticae 38. 35-37.

Zabrocki, L. 1963. Wspólnoty komunikatywne w genezie i rozwoju języka niemieckiego: Cz. 1. Wrocław: Zakład Narodowy im. Ossolińskich.

Zgółka, T. 1980. Język. kompetencja. Gramatyka: studium $z$ metodologii lingwistyki. Poznań: Państwowe Wydawnictwo Naukowe.

Żywiczyński, P. i S. Wacewicz. 2015. Ewolucja języka. W stronę hipotez gesturalnych. Toruń: Wydawnictwo Naukowe Uniwersytetu Mikołaja Kopernika. 